\title{
ANALISIS FLYPAPER EFFECT PADA BELANJA DESA DI KABUPATEN SIAK
}

\author{
Winda Hartati ${ }^{*}$, Taufeni Taufik ${ }^{2}$ \\ ${ }^{12}$ Program Studi Magister Akuntansi, Fakultas Ekonomi dan Bisnis, Universitas Riau, \\ Pekanbaru \\ *E-mail: windahartati12@yahoo.co.id
}

\begin{tabular}{|c|c|}
\hline Keywords & Abstract \\
\hline $\begin{array}{l}\text { Village Income, } \\
\text { Village Fund } \\
\text { Allocation, } \\
\text { Village Fund, } \\
\text { Village Expenditure, } \\
\text { Flypaper Effect }\end{array}$ & $\begin{array}{l}\text { The flypaper effect is a economic phenomenon shows that a } \\
\text { government grant to a recipient municipality increases the level of } \\
\text { local public spending more than an increase in local income of an } \\
\text { equivalent size. This study aims to analyze flypaper effect of village } \\
\text { income, village fund allocation, and fund allocation on village } \\
\text { expenditure of village in Siak Districts. Secondary data are used in this } \\
\text { research, that is village financial report in 2015-2018. This research }\end{array}$ \\
\hline Article Information & $\begin{array}{l}\text { uses purposive sampling with sampling method according to certain } \\
\text { criteria. This study obtained } 157 \text { villages as sample and analyzed by }\end{array}$ \\
\hline $\begin{array}{l}\text { Received: } \\
\text { 2020-05-20 } \\
\text { Accepted: } \\
\text { 2020-06-07 } \\
\text { Available Online: } \\
\text { 2020-07-23 }\end{array}$ & $\begin{array}{l}\text { multiple linier regression analysis using SPSS } 23.00 \text { program. The } \\
\text { result showed that in partial research indicates that Village Income, } \\
\text { Village Fund Allocation and Fund Allocation have effect to } \\
\text { Expenditure Village. This research too show that there has been a } \\
\text { Flypaper Effect on Village Expenditure of village in Siak Regency. It } \\
\text { can be seen from the coefficient of determination of Village Fund } \\
\text { Allocation and Village Funds that are greater than the coefficient of } \\
\text { determination of Original Village Income on Village Expenditure. }\end{array}$ \\
\hline
\end{tabular}

\section{PENDAHULUAN}

Fenomena flypaper effect membawa implikasi lebih luas bahwa transfer dapat meningkatkan belanja daerah/desa yang lebih besar daripada penerimaan transfer itu sendiri (Turnbull dalam Gede, 2015). Flypaper effect dapat terjadi dalam dua versi pertama merujuk pada peningkatan pendapatan lokal dan anggaran belanja pemerintah yang berlebihan. Kedua mengarah pada elastisitas pengeluaran terhadap transfer yang lebih tinggi daripada elastisitas pengeluaran terhadap penerimaan pendapatan lokal.

Dalam penelitian ini, penulis melakukan analisis flypaper effect belanja desa dengan mengobservasi desa pada Kabupaten Siak sebagai lokasi penelitian. Sebab secara khusus melalui nawa cita Presiden Republik Indonesia, bantuan transfer berupa dana desa di harapkan mampu mengurangi jumlah desa tertinggal sampai 5.000 desa, serta meningkatkan jumlah desa mandiri sedikitnya 2.000 desa pada tahun 2019 (Indrawati, 2017). 
Namun baru-baru ini, berdasarkan pernyataan Direktur Fasilitasi Keuangan dan Aset Pemerintahan Desa Kementerian Dalam Negeri (Kemendagri), fakta justru menunjukkan bahwa dana desa merupakan sumber keuangan yang paling diimpikan pemerintah desa. Sebab secara umum 80 persen (80\%) anggaran desa berasal dari dana desa. Selain dana desa, sumber keuangan desa adalah pendapatan asli desa itu sendiri. Akan tetapi, baru sekitar lima persen (5\%) dari total desa di Indonesia sebanyak 74.954 yang sudah mampu mengumpulkan pendapatan asli desa lebih dari besaran dana desa (Kartika, 2019). Akibatnya, dari tahun ke tahun Pemerintah Desa menuntut transfer yang lebih besar dari pemerintah pusat maupun daerah.

Berdasarkan hasil survey pendahuluan di Dinas Pemberdayaan Masyarakat dan Kampung (DPMK) Pemerintahan Kabupaten Siak melalui data laporan keuangan desa, didapatkan data APBDesa tahun 2015-2018 yang digambarkan dalam grafik berikut:

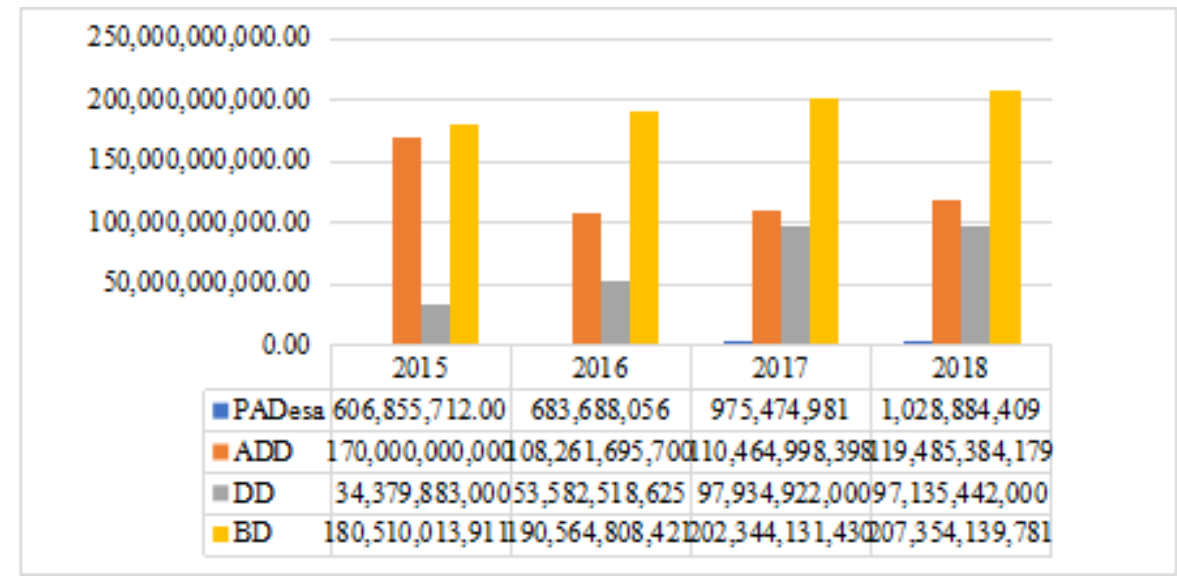

\section{Gambar 1}

\section{Trend APBDesa 2015-2018 (dalam rupiah)}

Sumber: Data APBDesa tahun 2015-2018

Dari grafik di atas, terlihat bahwa sejak tahun 2015 hingga 2018 pendapatan desa secara keseluruhan mengalami peningkatan begitupun dengan belanja desa. Namun porsi pendapatan asli desa hanya sebesar $0,5 \%$ dari besarnya belanja desa. Sementara porsi alokasi dana desa dan dana desa masih sangat dominan. Hal ini menunjukkan indikasi terjadinya flypaper effect pada belanja desa di Kabupaten Siak. Oleh karena flypaper effect terjadi ketika pengaruh pendapatan transfer lebih besar terhadap belanja desa dibandingkan pengaruh pendapatan asli desa terhadap belanja desa.

Penelitian sebelumnya telah banyak mengangkat permasalahan flypaper effect pada dana transfer di tingkat kabupaten/daerah. Misalnya di Jerman, Kalb (2010) menemukan bahwa bantuan transfer berpengaruh negatif terhadap efisiensi biaya. Artinya besarnya bantuan transfer justru meningkatkan belanja dan mengurangi efisiensi biaya. Kemudian hasil 
penelitian Pevcin (2011) di Slovenia menunjukkan bahwa minimalisasi pengeluaran transfer dapat berpengaruh negatif terhadap belanja. Selanjutnya Kang dan Setiawan (2012) yang melakukan penelitian pada kabupaten kota di Indonesia justru menemukan hasil penelitian yang berbeda. Pengaruh pendapatan asli daerah terhadap belanja daerah justru lebih besar dibanding pengaruh dana perimbangan terhadap belanja daerah. Hal ini menunjukkan bahwa tidak terjadi flypaper effect belanja daerah pada kabupaten kota di Indonesia. Sama halnya dengan penelitian Mentayani et al. (2012), yang melakukan penelitian di kabupaten/kota di Provinsi Kalimantan Selatan tahun 2010. Hasil penelitian menunjukkan bahwa tidak terjadi flypaper effect. Begitu pula dengan penelitian Herdiyanto dan Rahayu (2016), yang meneliti fenomena flypaper effect di kota Bandung selama tahun 2008-2012 dengan hasil tidak terjadi flypaper effect.

Namun baru-baru ini Amalia (2017) justru menemukan bahwa telah terjadi flypaper effect belanja daerah pada kabupaten kota di Indonesia. Artinya pengaruh dana perimbangan terhadap belanja daerah lebih besar daripada pengaruh pendapatan asli daerah terhadap belanja daerah. Didukung oleh penelitian Ansori dan Mutmainah (2018) yang melakukan penelitian pada pemerintah kabupaten/kota di pulau Bali dan Nusra.

Berdasarkan uraian di atas, peneliti tertarik melakukan penelitian tentang analisis flypaper effect namun pada tingkat Pemerintah Desa, yaitu pada desa di Kabupaten Siak. Mengingat bahwa pemerintah desa merupakan lembaga pemerintahan yang paling dekat dengan masyarakat. Sisi menarik pada desa di Kabupaten Siak sebagai observasi penelitian adalah terkait kearifan lokal penggunaan nama "kampung" sebagai perubahan penyebutan nama desa. Hal ini berdasarkan Peraturan Daerah Kabupaten Siak Nomor 01 tahun 2015 tentang Perubahan Penamaan Desa Menjadi kampung. Disamping itu adanya perbedaan karakteristik dalam pengelolaan belanja pada desa dan daerah juga menjadi perhatian penting dalam pemilihan lingkup penelitian ini. Sebab menurut Peraturan Pemerintah Nomor 47 Tahun 2015 tentang Peraturan Pelaksanaan Undang-Undang Nomor 6 Tahun 2014 tentang Desa, bahwa porsi belanja desa yang digunakan untuk membiayai penyelanggaraan pemerintahan desa, pelaksanaan pembangunan desa, pembinaan kemasyarakatan desa, dan pemberdayaan masyarakat desa jauh lebih besar yaitu 70\% dari anggaran yang telah ditetapkan. Besarn ya persentase belanja untuk kepentingan masyarakat ini diharapkan lebih dapat meningkatkan kemandirian desa. Sehingga dengan perbedaan tersebut, penelitian ini diharapkan dapat memberikan gambaran terkait terjadinya fenomena flypaper effect. 
Oleh sebab itu, penelitian ini mengacu pada penelitian sebelumnya terkait flypaper effect. Namun yang membedakan dengan penelitian sebelumnya adalah pada lingkup penelitian yaitu Pemerintahan Desa. Dengan demikian tujuan penelitian ini adalah: 1) Untuk menguji dan menganalisis pengaruh pendapatan asli desa terhadap belanja desa. 2) Untuk menguji dan menganalisis pengaruh alokasi dana desa terhadap belanja desa. 3) Untuk menguji dan menganalisis pengaruh dana desa terhadap belanja desa. 4) Untuk menguji dan menganalisis terjadinya flypaper effect pada pengaruh alokasi dana desa dan dana desa secara simultan dengan pendapatan asli desa terhadap belanja desa di Kabupaten Siak.

\section{PENGEMBANGAN HIPOTESIS}

\section{Pengaruh Pendapatan Asli Desa Terhadap Belanja Desa}

Peningkatan kapasitas pendapatan asli desa diharapkan mampu memberikan dampak yang signifikan terhadap pengalokasian anggaran belanja desa (Andari et al, 2017). Semakin besar pendapatan asli desa yang diperoleh memungkinkan desa menjadi mandiri, sehingga dapat memenuhi kebutuhan belanja desa-nya sendiri tanpa menunggu bantuan dari pemerintah pusat maupun daerah. Begitu pula sebaliknya, semakin rendah pendapatan asli desa yang diperoleh suatu desa maka desa tidak dapat memenuhi seluruh belanja desanya. Menurut Yuni (2017), melalui inovasi dalam menggali potensi yang dimiliki desa, pendapatan asli desa yang tinggi dapat memenuhi kebutuhan belanja desa terutama di bidang kesehatan yang merupakan kebutuhan rutin. Hal tersebut diperkuat oleh penelitian yang dilakukan oleh Sulistyoningtyas (2017), bahwa pendapatan asli desa berpengaruh signifikan terhadap Belanja Desa. Serta didukung oleh penelitian Dewi (2018), bahwa pendapatan asli desa dan alokasi dana desa berpengaruh langsung terhadap belanja desa dan kemiskinan.

Berbeda dengan penelitian Habibah (2017), bahwa secara parsial pendapatan asli desa tidak berpengaruh secara signifikan terhadap belanja desa di bidang Pendidikan. Selanjutnya Murti (2018), bahwa pendapatan asli desa tidak berpengaruh dan negatif signifikan terhadap belanja desa. Sama halnya dengan Annisa et al. (2019) bahwa pendapatan asli desa tidak berpengaruh dan negatif signifikan terhadap belanja desa. Hal ini terjadi karena sumber pendapatan asli desa dari hasil usaha dan swadaya serta retribusi objek wisata desa kurang dikembangkan dan dimanfaatkan secara maksimal. Sehingga menyebabkan kurangnya penghasilan dari pendapatan asli desa, yang hanya cukup untuk menambah penghasilan tetap kepala desa dan perangkatnya. Berdasarkan landasan teori dan hasil penelitian terdahulu, maka hipotesis penelitian dirumuskan sebagai berikut:

\section{$\mathrm{H}_{1}$ : Pendapatan Asli Desa berpengaruh terhadap Belanja Desa.}




\section{Pengaruh Alokasi Dana Desa Terhadap Belanja Desa}

Kurangnya kemampuan desa dalam memaksimalkan pendapatan asli desa menjadikan desa cenderung memiliki ketergantungan pada sumber pendapatan yang lain yaitu pendapatan transfer berupa alokasi dana desa. Tujuan pemberian alokasi dana desa ini adalah mendukung ketersediaan dana dalam memenuhi kebutuhan belanja desa untuk menjalankan fungsi yang telah didesentralisasikan.

Dalam beberapa literatur ekonomi dan keuangan disebutkan bahwa pendapatan mempengaruhi belanja. Sementara sebagian lainnya menyatakan bahwa besarnya pendapatan tidak mempengaruhi belanja. Seperti halnya yang dinyatakan oleh Pevcin (2011) bahwa pengurangan jumlah transfer menyebabkan penurunan dalam belanja. Namun demikian, pada dasarnya besarnya pendapatan sekaligus dapat mempengaruhi tingkat kemandirian. Demikian halnya dengan alokasi dana desa. Semakin besar alokasi dana desa yang diterima menunjukkan bahwa tingkat ketergantungan pemerintah desa terhadap bantuan transfer masih sangat tinggi. Ini menandakan bahwa desa tersebut belum mandiri, begitu juga sebaliknya.

Penelitian Sulistyoningtyas (2017) menyatakan bahwa belanja desa lebih banyak dibiayai oleh alokasi dana desa dibandingkan pendapatan asli desa. Hal ini menyebabkan dalam mengembangkan potensi desa, pemerintah desa masih bergantung pada dana pemberian dari pemerintah daerah. Penelitian Yuni (2017) menyatakan bahwa alokasi dana desa berpengaruh positif signifikan terhadap belanja desa. Selanjutnya penelitian Prabawa (2015), memberikan bukti bahwa pemanfaatan alokasi dana desa dialokasikan sesuai dengan prioritas desa. Semakin besar alokasi dana desa yang diterima suatu desa maka tingkat ketergantungan dalam membiayai pengeluaran desa semakin tinggi.

Berbeda dengan penelitian yang dilakukan oleh Habibah (2017). Hasil penelitian ini menunjukkan bahwa sebagian besar alokasi dana desa belum banyak dialokasikan terhadap belanja desa bidang pendidikan di desa-desa sekabupaten Sukaharjo, karena pendanaanya diprioritaskan untuk program pemberdayaan masyarakat dan publik. Berdasarkan landasan teori dan hasil penelitian terdahulu, maka hipotesis penelitian dirumuskan sebagai berikut:

\section{H2: Alokasi Dana Desa berpengaruh terhadap Belanja Desa.}

\section{Pengaruh Dana Desa terhadap Belanja Desa}

Pada tingkat kabupaten, dana desa sama halnya dengan DAU dan DAK, yaitu pendapatan yang berasal dari dana transfer. Prioritas penggunaan dana desa adalah untuk pemberdayaan masyarakat desa dan pembangunan desa yang tertinggal. Pemberdayaan yang dilakukan terutama berkaitan dengan peningkatan kualitas perencanaan desa dan 
pengembangan potensi ekonomi lokal yang potensial. Oleh karena itu, diharapkan proses pembangunan di pedesaan akan berlangsung dengan efektif dan sesuai dengan rencana pembangunan yang diharapkan pemerintah. Dengan demikian besarnya dana desa berpengaruh besar pada kontribusi belanja desa.

Penelitian Setyaningsih (2017) memberikan hasil bahwa dana desa berpengaruh signifikan terhadap belanja desa dalam hal pembangunan desa, pembinaan kemasyarakatan desa, dan pemberdayaan masyarakat terhadap penduduk miskin. Penelitian Habibah (2017) menunjukkan bahwa dana desa memiliki pengaruh signifikan terhadap belanja desa bidang pendidikan. Pemerintah pusat memberikan dana desa yang penggunaanya diprioritaskan untuk mendanai pembangunan desa dan bidang pemberdayaan masyarakat desa. Belanja desa bidang pendidikan merupakan salah satu dalam meningkatkan pembangunan.

Sementara penelitian Mucharomah (2018), memberikan bukti bahwa dana desa berpengaruh secara negatif signifikan terhadap belanja desa bidang pemberdayaan masyarakat. Sedangkan penelitian Purbasari et al. (2018) menunjukkan bahwa dana desa tidak berpengaruh secara signifikan terhadap belanja modal desa. Oleh karena berdasarkan PMK 49 tahun 2016, diketahui rumus dana desa di setiap desa sebesar 90\%. Dana desa disetiap desa memiliki jumlah yang hampir sama, sehingga varian dana desa tidak sejalan dengan varian belanja modal di tiap-tiap desa. Berdasarkan tinjauan teori dan review penelitian terdahulu, maka hipotesis penelitian dirumuskan sebagai berikut:

\section{H3: Dana Desa berpengaruh terhadap Belanja Desa.}

\section{Flypaper Effect Pada Pengaruh Alokasi Dana Desa dan Dana Desa Secara Simultan}

\section{Dengan Pendapatan Asli Desa Terhadap Belanja Desa}

Flypaper effect dianggap sebagai suatu anomali dalam perilaku rasional bahwa transfer dianggap sebagai tambahan pendapatan masyarakat, sehingga mestinya dibelanjakan dengan cara yang sama pula. Hal ini berdampak pada meningkatnya ketergantungan dan ketidakmandirian pemerintah desa. Oleh karena pemerintah desa lebih cenderung menanti bantuan transfer daripada mengoptimalkan pendapatan asli desa mereka sendiri.

Anomali tersebut memicu diskusi yang intensif di antara pakar ekonomi, sehingga menghasilkan beberapa penjelasan yang ditawarkan. Diantaranya bahwa flypaper effect dikelompokan ke dalam dua model, yaitu model birokratik dan model ilusi fiskal. Model birokratik merupakan pandangan tentang flypaper effect dari sudut pandang birokrat, sedangkan model ilusi fiskal merupakan sudut pandang ,masyarakat yang mengalami keterbatasan informasi terhadap anggaran pemerintah. 
Penelitian tentang flypaper effect pada tingkat kabupaten sudah banyak dilakukan. Seperti halnya yang dilakukan oleh Maimunah (2006), dengan mengambil sampel pada kabupaten/kota di Pulau Sumatera. Hasil penelitian ini menunjukkan bahwa secara terpisah maupun serempak, DAU dan PAD berpengaruh secara signifikan terhadap belanja daerah. Ini berarti telah terjadi flypaper effect pada belanja daerah kabupaten/kota di Pulau Sumatera.

Penelitian lain dilakukan oleh Tuasikal (2008) menunjukkan bahwa DAU, DAK, dan PAD berpengaruh positif terhadap alokasi belanja modal daerah kabupaten/kota di Indonesia, sementara PDRB tidak berpengaruh. Kusumadewi dan Rahman (2007) menegaskan bahwa pengaruh DAU terhadap belanja daerah lebih signifikan daripada PAD terhadap belanja daerah. Prakosa (2004) dalam penelitiannya menyatakan bahwa dalam model prediksi belanja daerah, daya prediksi DAU terhadap belanja daerah lebih tinggi dibanding daya prediksi PAD. Berdasarkan uraian dari penelitian-penelitian tersebut maka hipotesis untuk mengetaui ada tidaknya flypaper effect adalah:

\section{H4: Terjadi Flypaper Effect pada Pengaruh Alokasi Dana Desa dan Dana Desa secara} simultan lebih besar terhadap Belanja Desa daripada pengaruh Pendapatan Asli Desa terhadap Belanja Desa.

\section{Model Penelitian}

Model penelitian yang diajukan dalam gambar berikut ini merupakan kerangka konseptual dan sebagai alur pemikiran dalam pengujian hipotesis:

Variabel Independen Variabel Dependen

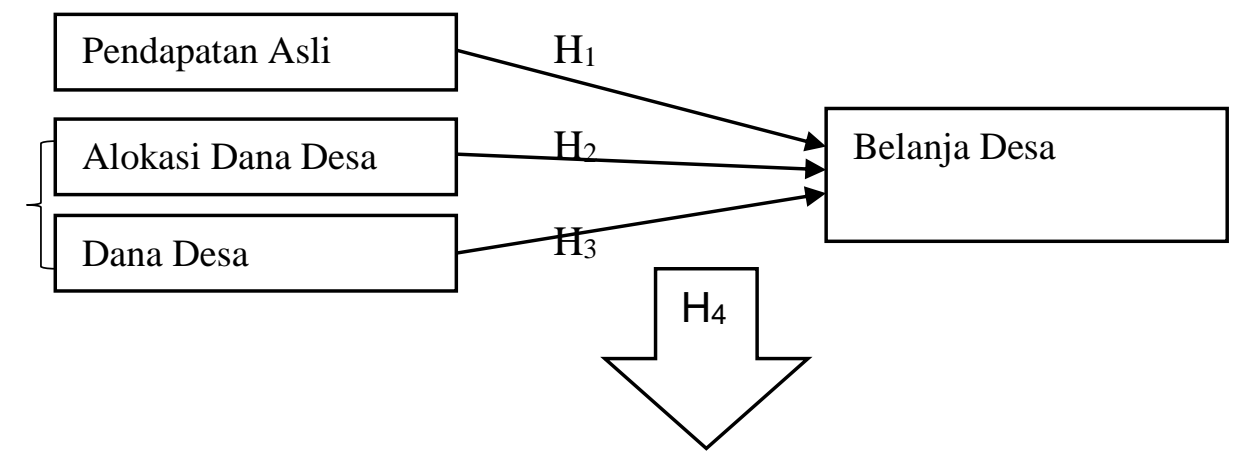

Terjadi Flypaper Effect apabila: (1) Pengaruh ADD dan DD secara simultan lebih besar dibanding pengaruh PADesa terhadap BD, atau (2) PADesa tidak berpengaruh terhadap $\mathrm{BD}$

\section{Gambar 2}

\section{Model Penelitian}




\section{METODE PENELITIAN}

\section{Populasi dan Sampel}

Populasi dalam penelitian ini adalah kampung pada Kabupaten Siak, yang terdiri dari 122 kampung. Metode pengambilan sampel dalam penelitian ini menggunakan metode purposive sampling. Sehingga diperoleh sampel dalam penelitian ini sebanyak 361 kampung. Kriteria pengambilan sampel tergambar dalam tabel berikut:

\section{Tabel 1}

\section{Hasil Seleksi Sampel Desa}

\begin{tabular}{clc}
\hline No & \multicolumn{1}{c}{ Kriteria } & Jumlah Observasi \\
\hline 1 & Seluruh kampung di Kabupaten Siak Tahun 2015 s/d 2018 & 488 \\
2 & $\begin{array}{l}\text { Kampung pada Kabupaten Siak yang tidak mengumpulkan } \\
\text { Anggaran Pendapatan dan Belanja Desa Tahun 2015 s/d 2018 }\end{array}$ & 0 \\
3 & $\begin{array}{l}\text { Kampung yang tidak memiliki data keuangan lengkap Tahun 2015 } \\
\text { s/d 2018 }\end{array}$ & $(127)$ \\
\hline
\end{tabular}

Sumber: Hasil Olahan Data (2020)

\section{Variabel Dependen}

Variabel dependen dalam penelitian ini adalah belanja desa. Komponen belanja desa terdiri dari belanja per bidang dan belanja prioritas dalam Laporan Keuangan Desa tahun 2015-2018. Belanja desa dapat diukur dengan indikator sebagai berikut:

Belanja Desa $=$ Belanja Langsung + Belanja Tidak Langsung

\section{Variabel Independen}

Variabel independen dalam penelitian akan dijelaskan mengenai definisi dan pengukurannya sebagai berikut:

Pendapatan Asli Desa (PADesa)

Menurut Permendagri No 113 Tahun 2014 PADesa merupakan penerimaan uang dari hasil usaha, hasil aset, swadaya, partisipasi dan gotong royong serta lain-lain PADesa. PADesa dalam penelitian ini diketahui dari Laporan Keuangan Desa tahun 2015-2018. Indikator dari pendapatan asli desa yaitu:

$$
\text { PADesa }=\mathrm{HU}+\mathrm{HA}+\mathrm{SW}+\text { Lain-lain }
$$

Dimana: HU = Hasil Usaha; HA = Hasil Aset; dan SW = Swadaya

Alokasi Dana Desa $(A D D)$

Menurut PP No 47 Tahun 2015, Alokasi dana Desa adalah dana yang dialokasikan minimal 10\% dari dana perimbangan yang diterima oleh kabupaten atau kota dalam Anggaran Pendapatan dan Belanja Daerah kabupaten/kota setelah dikurangi Dana Alokasi Khusus. Alokasi Dana Desa dalam penelitian ini diketahui dari Laporan Keuangan Desa tahun 2015- 
2018. Alokasi dana desa diukur dengan rumus berikut:

$$
\mathrm{ADD}=\mathrm{AD}+\mathrm{AF}
$$

Dimana: $\mathrm{AD}=$ Alokasi Dasar dan $\mathrm{AF}=$ Alokasi Formula

Dana Desa

PP No 8 Tahun 2016 menyatakan bahwa dana desa merupakan pendapatan yang diterima oleh pemerintah desa, bersumber dari APBN ditransfer melalui APBD dan digunakan untuk membiayai penyelenggaraan pemerintahan, pelaksanaan pembangunan, pembinaan kemasyarakatan, dan pemberdayaan masyarakat. Dana Desa diketahui dari Laporan Keuangan Desa tahun 2015-2018. Dana desa diukur dengan indikator sebagai berikut:

$\mathrm{DD}=(30 \% \mathrm{x}$ jumlah penduduk $)+(20 \% \mathrm{x}$ luas wilayah $)+(50 \% \mathrm{x}$ angka kemiskinan $)$

Untuk flypaper effect tidak dideskripsikan definisi operasionalnya. Hal ini dikarenakan flypaper effect bukan merupakan variabel penelitian. Flypaper effect dalam penelitian ini merupakan situasi yang dihasilkan oleh ketiga variabel di atas. Dimana ketika koefisien ADD dan DD lebih berpengaruh signifikan daripada PADesa, atau ketika PAdesa tidak berpengaruh terhadap belanja desa maka kondisi ini disebut flypaper effect.

\section{Metode Analisis Data}

Analisis data yang digunakan dalam penelitian ini adalah analisis regresi berganda dan analisis regresi sederhana.

Analisis Regresi

Berikut adalah model persamaan yang digunakan dalam pengujian hipotesis 1, 2, 3, dan 4 pada penelitian ini:

$$
\begin{aligned}
& \text { BD }=\alpha+\beta_{1} \text { PADesa }+\beta_{2} \text { ADD }+\beta_{3} \text { DD }+\mathrm{e} \\
& \text { BD }=\alpha+\beta_{1} \text { ADD }+\beta_{2} \text { DD }+\mathrm{e} \\
& \text { BD }=\alpha+\beta_{1} \text { PADesa }+\mathrm{e}
\end{aligned}
$$

Keterangan:

$\mathrm{BD}=$ Belanja Desa

$\alpha \quad=$ Konstanta

$\beta_{1}-\beta_{3}=$ Koefisien regresi masing-masing $X$

PADesa $=$ Pendapatan Asli Desa

$\mathrm{ADD}=$ Alokasi Dana Desa

DD = Dana Desa

e $\quad=$ Koefisien error 


\section{Pengujian Hipotesis Penelitian}

Untuk menguji hipotesisi pertama $\left(\mathrm{H}_{1}\right)$, hipotesis kedua $\left(\mathrm{H}_{2}\right)$ dan hipotesis ketiga $\left(\mathrm{H}_{3}\right)$ dalam penelitian ini digunakan uji t, dengan tingkat keyakinan 95\% $(\alpha=0,05)$. Sementara untuk menguji hipotesis keempat $\left(\mathrm{H}_{4}\right)$ dalam penelitian ini digunakan uji $\mathrm{f}$, dengan tingkat keyakinan $95 \%(\alpha=0,05)$.

Selain itu dalam menguji $\mathrm{H}_{4}$ digunakan pula uji koefesien determinasi $\left(\mathrm{R}^{2}\right)$, yaitu untuk melihat berapa proporsi variasi dari variabel bebas secara bersama-sama dalam mempengaruhi variabel tidak bebas. Kaidah pengambilan keputusan adalah:

1. Jika nilai adjusted $R$ Square ADD dan DD secara simultan $>$ adjusted $R$ Square PADesa maka $\mathrm{H}_{4}$ diterima dan $\mathrm{H}_{0}$ ditolak.

2. Jika nilai adjusted $R$ Square ADD dan DD secara simultan < adjusted $R$ Square PADesa maka $\mathrm{H}_{4}$ ditolak dan $\mathrm{H}_{0}$ diterima.

\section{HASIL PENELITIAN DAN PEMBAHASAN}

\section{Gambaran Umum Lokasi Penelitian}

Kabupaten Siak adalah sebuah kabupaten di Provinsi Riau, Indonesia. Secara fisik geografis memiliki kawasan pesisir pantai yang berhampiran dengan sejumlah negara tetangga dan masuk kedalam daerah segitiga pertumbuhan (growth triangle) Indonesia Malaysia - Singapura. Batas Wilayah Administrasi sebelah Utara Kabupaten Siak berbatasan dengan Kabupaten Bengkalis. Disebelah selatan berbatasan dengan Kabupaten Pelalawan. Di sebelah Barat berbatasan dengan Kabupaten Kampar dan Kota Pekanbaru sedangkan disebelah Timur berbatasan dengan Kabupaten Kepulauan Meranti.

\section{Hasil Penentuan Sampel Penelitian}

Hasil penentuan sampel dalam penelitian ini dapat dilihat pada tabel berikut:

\section{Tabel 2}

\section{Hasil Penentuan Sampel Penelitian}

\begin{tabular}{|c|c|c|}
\hline No & Kriteria & Jumlah Observasi \\
\hline 1 & Seluruh kampung di Kabupaten Siak Tahun 2015 s/d 2018 & 488 \\
\hline 2 & $\begin{array}{l}\text { Kampung pada Kabupaten Siak yang tidak mengumpulkan } \\
\text { Anggaran Pendapatan dan Belanja Desa Tahun } 2015 \mathrm{~s} / \mathrm{d} 2018\end{array}$ & 0 \\
\hline 3 & $\begin{array}{l}\text { Kampung yang tidak memiliki data keuangan lengkap Tahun } 2015 \\
\text { s/d } 2018\end{array}$ & (127) \\
\hline & Jumlah sampel penelitian & 361 \\
\hline & Data outlier & (204) \\
\hline & Jumlah sampel setelah outlier & 157 \\
\hline
\end{tabular}

Sumber: Hasil Olahan Data (2020) 


\section{Hasil Analisis Statistik Deskriptif}

Hasil analisis statistik deskriptif penelitian ini dapat dilihat pada tabel berikut:

\section{Tabel 3}

\section{Hasil Analisis Statistik Deskriptif}

\begin{tabular}{lrrrrr}
\hline & N & \multicolumn{1}{c}{ Minimum } & \multicolumn{1}{c}{ Maximum } & \multicolumn{1}{c}{ Mean } & \multicolumn{1}{c}{ Std. Deviation } \\
\hline PADesa & 361 & 17000.00 & 156218884.00 & 9100410.4100 & 14254395.82105 \\
ADD & 361 & 7052732.00 & 4889898479.00 & 963797322.8670 & 468698384.96578 \\
DD & 361 & 156218884.00 & 1606318000.00 & 675763795.5152 & 215676471.39825 \\
BD & 361 & 73021850.00 & 5074908408.00 & 1658822915.6787 & 606074318.11878 \\
Valid N (listwise) & 361 & & & &
\end{tabular}

\section{Sumber: Data diolah Peneliti (2020)}

Dari hasil analisis deskriptif tabel di atas, dapat dideskripsikan bahwa nilai rata-rata pendapatan asli desa lebih kecil daripada standar deviasinya. Ini menunjukkan bahwa data tidak berdistribusi dengan normal dan dapat menyebabkan bias. Sementara variabel alokasi dana dan dana desa memiliki rata-rata yang lebih besar daripada standar deviasinya. Hal ini menunjukkan bahwa variabel tersebut dapat berkontribusi dengan baik dan tidak menunjukkan bias.

Dalam kasus penelitian ini, nilai mean variabel pendapatan asli desa lebih kecil daripada standar deviasinya. Hal ini menunjukkan di dalam data terdapat outlier (data yang terlalu ekstrim). Adapun hasil analisis statistik deskriptif setelah menghilangkan data outlier adalah sebagai berikut:

\section{Tabel 4}

\section{Hasil Analisis Statistik Deskriptif (setelah data outlier dihilangkan)}

\begin{tabular}{lrrrrr} 
& $\mathrm{N}$ & \multicolumn{1}{c}{ Minimum } & \multicolumn{1}{c}{ Maximum } & \multicolumn{1}{c}{ Mean } & \multicolumn{1}{c}{ Std. Deviation } \\
\hline PADesa & 157 & 1914000.00 & 9831000.00 & 5188634.892 & 1687547.110 \\
ADD & 157 & 511233095.00 & 1294788736.00 & 793878823.2 & 169408468.3 \\
DD & 157 & 266449856.00 & 907359735.00 & 704313968.1 & 129417453.7 \\
BD & 157 & 1023129420.00 & 1971418750.00 & 1574010193 & 206848831.3 \\
Valid N (listwise) & 157 & & & & \\
\hline
\end{tabular}

Sumber: Data diolah Peneliti (2020)

Setelah data outlier dihilangkan, terlihat bahwa mean masing-masing variabel mempunyai nilai yang lebih besar daripada standar deviasinya. Dengan demikian diketahui bahwa data yang layak diolah adalah sebanyak 157 data sisanya sebanyak 204 data dianggap outlier.

\section{Hasil Uji Normalitas}

Untuk menguji normalitas residual pada penelitian ini digunakan uji statistik nonparametrik Kolmogorov-Sminorv (K-S) dengan nilai signifikansi sebesar 0,05. Setelah dilakukan pengolahan melalui program IBM Statistics SPSS 23.00 for windows, diperoleh hasil sebagai berikut: 


\begin{tabular}{llr}
\hline & One-Sample Kolmogorov-Smirnov Test \\
\hline $\mathrm{N}$ & \multicolumn{1}{c}{ Unstandardized Residual } \\
\hline Normal Parameters ${ }^{\text {a,b }}$ & & 157 \\
& Mean & .0000001 \\
Most Extreme Differences & Std. Deviation & 157297076.6 \\
& Absolute & .049 \\
& Positive & .049 \\
Test Statistic & Negative & -.025 \\
Asymp. Sig. (2-tailed) & & .049 \\
\hline a. Test distribution is Normal. & & $.200^{\text {c.d }}$ \\
b. Calculated from data. & \\
c. Lilliefors Significance Correction. & \\
d. This is a lower bound of the true significance. & \\
\hline
\end{tabular}

Sumber: Data diolah Peneliti (2020)

Berdasarkan hasil uji one-sample Kolmogorov sminorv di atas menunjukkan nilai asymtatic significant sebesar $0,200^{\mathrm{cd}}$ di atas nilai signifikan 0,05 , maka dapat dianalisis bahwa variabel penelitian berdistribusi normal.

\section{Hasil Uji Multikolinearitas}

Hasil uji multikolinearitas dalam penelitian ini dapat dilihat pada tabel berikut:

Tabel 6

Hasil Uji Multikolinearitas

\begin{tabular}{lccc}
\hline \multicolumn{1}{c}{ Variabel } & Tolerance & VIF & Keterangan \\
\hline PADesa & .988 & 1.012 & Tidak terjadi multikolinearitas \\
ADD & .939 & 1.064 & Tidak terjadi multikolinearitas \\
DD & .938 & 1.066 & Tidak terjadi multikolinearitas \\
\hline
\end{tabular}

Sumber: Data diolah Peneliti (2020)

Tabel di atas menunjukkan bahwa nilai VIF untuk variabel PADesa, ADD dan DD masing-masing adalah sebesar 0.988, 0.939, dan 0.938. Sedangkan nilai tolerance dari masing-masing variabel adalah 1.012, 1.064, dan 1.066. Jadi dapat disimpulkan tidak terjadi multikolinearitas dalam model regresi yang digunakan.

\section{Hasil Uji Heteroskedastisitas}

Hasil dari uji heteroskedastisitas dengan menggunakan uji glejser terdapat pada tabel 6 berikut:

Tabel 7 Hasil Uji Heteroskedastisitas

\begin{tabular}{lccc}
\hline \multicolumn{1}{c}{ Variabel } & T & Sig & Keterangan \\
\hline PADesa & .000 & 1.000 & Tidak terjadi heteroskedastisitas \\
ADD & .000 & 1.000 & Tidak terjadi heteroskedastisitas \\
DD & .000 & 1.000 & Tidak terjadi heteroskedastisitas \\
\hline
\end{tabular}

Sumber: Data diolah peneliti (2020) 
Berdasarkan hasil uji glejser pada tabel di atas, diketahui bahwa setiap variabel bebas memiliki nilai signifikansi lebih besar dari 0,05 sehingga dapat dianalisa bahwa setiap variabel tidak ada gangguan heteroskedasitas pada model, sehingga memenuhi persyaratan untuk analisis regresi.

\section{Hasil Analisis Regresi}

Dari analisis statistik dengan menggunakan bantuan program IBM SPSS 23, hasil analisis regresi dapat dilihat sebagai berikut:

\section{Tabel 8}

Hasil Analisis Regresi Persamaan Pertama

\begin{tabular}{crrrr}
\hline Variabel & \multicolumn{1}{c}{ B } & \multicolumn{1}{c}{ Std. Error } & \multicolumn{1}{c}{ T } & \multicolumn{1}{c}{ Sig } \\
\hline (Constant) & 440146731.5 & 108649413.6 & 4.051 & .000 \\
PADesa & 16.178 & 7.580 & 2.134 & .034 \\
ADD & .536 & .077 & 6.924 & .000 \\
DD & .886 & .101 & 8.736 & .000
\end{tabular}

Sumber: Data diolah peneliti (2020)

Berdasarkan tabel diperoleh persamaan regresi sebagai berikut:

$$
\mathrm{BD}=440146731.5+16.178 \text { PADesa }+ \text { 0.536 ADD + 0.886 DD + e }
$$

\section{Tabel 9}

Hasil Analisis Regresi Persamaan Pertama

\begin{tabular}{crrrr}
\hline Variabel & \multicolumn{1}{c}{ B } & \multicolumn{1}{c}{ Std. Error } & \multicolumn{1}{c}{ T } & \multicolumn{1}{c}{ Sig } \\
\hline (Constant) & 500027692.2 & 106169769.8 & 4.710 & .000 \\
ADD & .549 & .078 & 7.036 & .000 \\
DD & .906 & .102 & 8.860 & .000 \\
\hline
\end{tabular}

Sumber: Data diolah peneliti (2020)

Berdasarkan tabel diperoleh persamaan regresi sebagai berikut:

$$
\mathrm{BD}=500027692.2+0.549 \text { ADD + 0.906 DD + e }
$$

\section{Tabel 10}

Hasil Analisis Regresi Persamaan Ketiga

\begin{tabular}{llrrrr}
\hline Variabel & B & Std. Error & T & \multicolumn{2}{c}{ Sig } \\
\hline & (Constant) & 1447660250 & 52631090.56 & 27.506 & .000 \\
& PADesa & 24.351 & 9.649 & 2.524 & .013 \\
\hline
\end{tabular}

Sumber: Data diolah peneliti (2020)

Berdasarkan tabel diperoleh persamaan regresi sebagai berikut:

$$
\mathrm{BD}=1447660250+24.351 \text { PADesa }+\mathrm{e}
$$

\section{Hasil Pengujian Hipotesis Penelitian}

Hasil pengujian hipotesis 1 - 4 dapat dilihat pada tabel dibawah : 


\section{Tabel 1}

\section{Hasil Pengujian Hipotesis}

\begin{tabular}{cccc}
\hline Hipotesis & t & Sig. & Keterangan \\
\hline H1 & 2.134 & .034 & Hipotesis Pertama Diterima \\
H2 & 6.924 & .000 & Hipotesis Kedua Diterima \\
H3 & 8.736 & .000 & Hipotesis Ketiga Diterima \\
H4 & 52.304 & .000 & Hipotesis Keempat Diterima \\
\hline
\end{tabular}

Sumber: Data diolah peneliti (2020)

Hipotesis pertama $\left(\mathrm{H}^{1}\right)$, hipotesis kedua $\left(\mathrm{H}^{2}\right)$, dan hipotesis ketiga $\left(\mathrm{H}^{1}\right)$ secara statistik didukung dan diterima karena memiliki nilai signifikansi lebih kecil dibandingkan level of significant yaitu sebesar $0.000<0.05$. Sama halnya dengan hipotesis keempat $\left(\mathrm{H}^{4}\right)$, secara statistik didukung dan diterima. Hal ini dapat dilihat dari nilai hasil uji f sebesar 52.304 dan nilai signifikansi lebih kecil dibandingkan level of significant yaitu sebesar $0.000<0.05$. Selain itu dilihat pula dari nilai Adjusted $R$ Square ADD dan DD secara simultan sebesar 0.397 lebih besar dari Adjusted $R$ Square PADesa terhadap BD sebesar 0.033. Sehingga diketahui bahwa variabel alokasi dana desa dan dana desa secara simultan berpengaruh lebih besar daripada pendapatan asli desa terhadap belanja desa. Dengan demikian hal ini menunjukkan bahwa telah terjadi flypaper effect belanja desa pada kampung di Kabupaten Siak.

\section{Analisis dan Pembahasan}

Pengaruh Pendapatan Asli Desa Terhadap Belanja Desa

Melalui hasil uji t diketahui bahwa PADesa memiliki nilai signifikansi lebih kecil dibandingkan level of significant yaitu sebesar $0.034<0.05$ dan nilai t-hitung sebesar 2.134 lebih besar dibandingkan t-tabel sebesar 1.9755903. Hal ini menunjukkan bahwa secara parsial variabel PAdesa berpengaruh terhadap belanja desa. Namun tidak menunjukkan pengaruh yang signifikan. Artinya pendapatan asli desa hanya memberikan kontribusi yang kecil terhadap belanja desa. Kecilnya pengaruh pendapatan asli desa terhadap belanja desa disebabkan oleh rendahnya pendapatan asli desa pada kampung di Kabupaten Siak tahun 2015-2018.

Bahkan dari hasil analisis data penelitian, terdapat beberapa kampung yang memiliki pendapatan asli desa jauh dari nilai rata-rata. Misalnya pada Kampung Sri Gemilang yang hanya memperoleh pendapatan asli desa sebesar 254.000 pada tahun 2016 kemudian menurun menjadi 17.000 pada tahun 2017. Kampung Dusun Pusaka hanya sebesar 204.771 pada tahun 2018, serta masih banyak lagi pendapatan asli yang masih sangat jauh dari nilai rata-rata. Namun demikian terdapat pula beberapa kampung di Kabupaten Siak yang memperoleh 
pendapatan asli desa jauh di atas nilai rata-rata seperti pada Kampung Mandi Angin sebesar 156.218.884 pada tahun 2018. Kampung Teluk Merbau sebesar 104.400.000 pada tahun 2015 kemudian sebesar 93.600.000 pada tahun 2016, dan beberapa kampung lainnya yang memiliki pendapatan asli desa jauh di atas nilai rata-rata. Ini menunjukkan bahwa pada kampung di Kabupaten Siak masih terdapat ketimpangan pendapatan asli desa yang cukup besar. Hal inilah yang kemudian menjadi penyebab menyimpangnya sebaran data penelitian yang diamati penulis. Sehingga mengakibatkan data penelitian menjadi bias (data outlier).

Ketimpangan pendapatan asli desa tersebut seharusnya dapat diminimalisir, sebab kampung di Kabupaten Siak memiliki sumber penghasilan yang potensial untuk menghasilkan pendapatan asli desa. Berupa pariwisata dan kekayaan sumber daya alamnya. Namun karena sumber pendapatan tersebut kurang dikembangkan dan dimanfaatkan secara optimal, sehingga menyebabkan kurangnya penghasilan dari pendapatan asli desa. Oleh sebab itu diperlukan upaya yang maksimal bagi pemerintah desa di Kabupaten Siak untuk mengoptimalkan kembali hasil aset, hasil usaha dan swadaya masyarakat yang berpotensi menghasilkan sumber penghasilan bagi desanya.

Hasil penelitian ini sama halnya dengan penelitian Oktora (2013), yang menyatakan bahwa PAD memiliki hubungan yang kurang erat dengan belanja modal dikarenakan proporsi PAD dalam komposisi pendapatan daerah rendah. Namun berpengaruhnya pendapatan asli desa terhadap belanja desa konsisten dengan penelitian Wardhana (2017) dan penelitian Suhairi (2016), yang menyatakan bahwa pendapatan desa memiliki hubungan yang erat dengan belanja desa. Konsisten pula dengan penelitian Sulistyoningtyas (2017). Hasil penelitian ini menunjukkan hasil bahwa pendapatan asli desa berpengaruh positif signifikan terhadap belanja desa.

Namun berbeda dengan penelitian Amnan (2019), bahwa pendapatan asli desa tidak berpengaruh dan negatif signifikan terhadap belanja desa. Berbeda pula dengan penelitian Murti (2018). Serta hasil penelitian Ferdiansyah (2018) yang menunjukkan bahwa Pendapatan Asli Daerah dan Dana Perimbangan tidak berpengaruh signifikan terhadap belanja daerah.

\section{Pengaruh Alokasi Dana Desa Terhadap Belanja Desa}

Berdasarkan hasil uji t pada tabel diketahui bahwa Variabel ADD memiliki nilai signifikansi lebih kecil dibandingkan level of significant yaitu sebesar $0.000<0.05$ dan nilai thitung sebesar 6.924 lebih besar dibandingkan t-tabel sebesar 1.9755903. Hal ini menunjukkan bahwa secara parsial variabel ADD berpengaruh terhadap belanja desa. Artinya bahwa alokasi dana desa memiliki kontribusi yang cukup besar dalam membiayai belanja 
desa pada pemerintah kampung di Kabupaten Siak.

Besarnya pengaruh alokasi dana desa terhadap belanja desa salah satunya disebabkan karena tingginya alokasi dana desa yang dimiliki oleh Kampung Perawang Barat pada tahun 2015, 2016 dan 2018 dan Kampung Tualang pada tahun 2017. Sehingga mengakibatkan belanja desa pada Kampung Tualang dan Perawang Barat menjadi semakin tinggi. Tanda unstandardized bermakna positif menunjukkan bahwa besarnya alokasi dana desa pada desa yang diamati, sedangkan simbol signifikan menunjukkan pengaruh yang bermakna atau berarti.

Semakin besar Alokasi Dana Desa akan semakin meningkatkan belanja desa. Oleh karena dengan Alokasi Dana Desa yang tinggi memungkinkan suatu daerah/desa untuk memenuhi kebutuhan belanja sendiri dengan tidak terlalu bergantung terhadap bantuan dari pemerintah pusat dan daerah. Pemerintah desa akan lebih berinovasi untuk menggali potensi yang dimiliki desa untuk menghasilkan dana yang tinggi agar dapat memenuhi kebutuhan termasuk belanja desa. Dengan demikian, hakikatnya pemberian alokasi dana desa diharapkan dapat meningkatkan kemandirian pada desa tersebut.

Alokasi dana desa merupakan dana yang bersumber dari pendapatan transfer. Jika dilihat dari penelitian tingkat Kabupaten/Kota, alokasi dana desa memiliki konsep yang sama dengan dana perimbangan karena sumber dananya berasal dari dana transfer. Di tingkat Kabupaten/Kota penelitian ini sejalan dengan Tuasikal (2008) yang menyatakan bahwa DAU dan DAK berpengaruh positif terhadap belanja modal Kabupaten/Kota di Indonesia. Di tingkat desa hasil penelitian ini konsisten dengan penelitian yang dilakukan Sulistyoningtyas (2017). Hasil penelitian menunjukkan bahwa Alokasi Dana Desa Berpengaruh terhadap Belanja Desa. Didukung pula oleh penelitian Prabawa (2015). Penelitian ini menunjukkan hasil bahwa penggunaan Alokasi Dana Desa dapat meningkatkan pembangunan di desa Loa Lepu.

Lain halnya dengan penelitian Handayani dan Nuraina (2012). Hasil penelitian ini menunjukkan bahwa DAK tidak berpengaruh terhadap belanja modal. Hal ini dikarenakan DAK yang diberikan Pemerintah Pusat memiliki sifat prioritas nasional. Sehingga Kabupaten/Kota yang menerima DAK wajib memberikan sekurang-kurangnya $10 \%$ dari total DAK untuk pendampingan kegiatan fisik. Pada penelitian tingkat desa, penelitian Wardhana (2017) memberikan bukti bahwa alokasi dana desa tidak berpengaruh secara signifikan terhadap belanja desa Bidang Pertanian. 


\section{Pengaruh Dana Desa Terhadap Belanja Desa}

Variabel dana desa memiliki nilai signifikansi lebih kecil dibandingkan level of significant yaitu sebesar $0.000<0.05$ dan nilai t-hitung sebesar 8.736 lebih besar dibandingkan t-tabel sebesar 1.9755903. Hal ini menunjukkan bahwa secara parsial variabel DD berpengaruh terhadap belanja desa.

Bahkan dari data penelitian diperoleh bukti bahwa peningkatan pendapatan transfer berupa dana desa terjadi dalam kurun waktu 2015-2018. Diiringi pula dengan peningkatan belanja desa yang cukup signifikan. Sehingga elastisitas peningkatan belanja desa terhadap pendapatan transfer berupa dana desa semakin tinggi. Oleh karena semakin besar dana desa yang diterima, semakin besar pula tingkat ketergantungan dalam membiayai kewenangan desa. Artinya kampung di Kabupaten Siak masih sangat bergantung pada dana yang diberikan pemerintah pusat berupa dana desa dalam mendanai penyelenggaraan kewenangan desanya.

Penelitian ini sejalan dengan penelitian Setianingtyas (2017). Hasil penelitian menunjukkan bahwa dana desa untuk pembangunan desa berpengaruh signifikan dengan arah positif terhadap angka kemiskinan. Penelitian ini juga didukung oleh penelitian yang dilakukan Habibah (2017), yang menunjukkan bahwa secara parsial dana desa berpengaruh secara signifikan terhadap belanja desa bidang pendidikan.

Akan tetapi penelitian ini berbeda dengan penelitian yang dilakukan oleh Yuni (2017). Hasil penelitian membuktikan bahwa variabel dana desa tidak berpengaruh secara signifikan terhadap Belanja Desa bidang kesehatan.

\section{Flypaper Effect Pada Pengaruh Alokasi Dana Desa dan Dana Desa Secara Simultan} Dengan Pendapatan Asli Desa Terhadap Belanja Desa

Dari hasil analisis statistik melalui uji koefisien determinasi, diketahui bahwa pengaruh alokasi dana desa dan dana desa secara simultan terhadap belanja desa sebesar 0.397 lebih besar daripada pengaruh pendapatan asli desa terhadap belanja desa sebesar 0,033. Hal ini membuktikan telah terjadi flypaper effect belanja desa di Kabupaten Siak. Kampung di Kabupaten Siak lebih cenderung mengandalkan pendapatan transfer berupa alokasi dana desa dan dana desa dibandingkan dengan pendapatan asli desa untuk membiayai belanja desanya. Padahal Kabupaten Siak dikenal dengan karakteristik pariwisata dan sumber daya alam yang dimiliki, namun ternyata fenomena flypaper effect masih terjadi.

Terjadinya Flypaper effect belanja desa ini menunjukkan bahwa pemerintah desa masih memiliki pola ketergantungan yang tinggi atas pendapatan transfer dari pemerintah pusat dan daerah. Pendapatan asli desa yang diperoleh pemerintah desa belum mampu 
memberikan pengaruh besar pada belanja desanya, sehingga pemerintah desa harus terus meningkatkan kemandirian ekonomi dengan lebih giat lagi dalam mengoptimalkan pendapatan asli desa untuk mengurangi fenomena flypaper effect yang terjadi. Tujuannya adalah agar tidak terus menerus terjadi pemborosan pengeluaran pemerintah melalui penggunaan bantuan transfer yang seharusnya digunakan untuk mengatasi ketimpangan pendapatan bagi desa yang memiliki pendapatan rendah.

Penelitian ini konsisten dengan penelitian yang dilakukan Salaweli et al (2016). Hasil penelitian membuktikan hasil bahwa secara silmutan DAU dan PAD berpengaruh signifikan terhadap belanja daerah dan juga didapat hasil bahwa terjadi flypaper effect dimana sumber penerimaan terbesar dari DAU mempengaruhi besaran belanja di tahun berikutnya. Penelitian ini juga konsisiten dengan penelitian Solikin (2016), yang membuktikan bahwa variable independen baik secara parsial maupun simultan berpengaruh positif. Konsisten pula dengan penelitian Panggabean 2017 di Sumatera Utara. Hasil penelitian ini menunjukkan bahwa telah terjadi Flypaper effect pada pengeluaran pemerintah kabupaten dan kota di provinsi Sumatera Utara. Namun, jika analisis dilakukan hanya pada pemerintah kota di provinsi Sumatera utara maka tidak ada flypaper effect pada belanja pemerintah.

\section{SIMPULAN}

Berdasarkan hasil penelitian yang dilakukan penulis, dapat disimpulkan bahwa pendapatan asli desa berpengaruh terhadap belanja desa. Namun dalam porsi yang tidak signifikan. Hal ini disebabkan oleh rendahnya pendapatan asli desa pada kampung di Kabupaten Siak tahun 2015-2018. Sementara Alokasi dana desa memiliki kontribusi yang cukup besar dalam membiayai belanja desa pada pemerintah kampung di Kabupaten Siak. Besarnya pengaruh alokasi dana desa terhadap belanja desa salah satunya disebabkan karena tingginya alokasi dana desa yang dimiliki oleh Kampung Perawang Barat pada tahun 2015, 2016 dan 2018 dan Kampung Tualang pada tahun 2017.

Demikian halnya dengan dana desa. Bahkan dari data penelitian diperoleh bukti bahwa peningkatan pendapatan transfer berupa dana desa terjadi dalam kurun waktu 20152018. Diiringi pula dengan peningkatan belanja desa yang cukup signifikan. Sehingga elastisitas peningkatan belanja desa terhadap pendapatan transfer berupa dana desa semakin tinggi. Artinya kampung di Kabupaten Siak masih sangat bergantung pada dana yang diberikan pemerintah pusat berupa dana desa dalam mendanai penyelenggaraan kewenangan desanya. Berdasarkan hasil penelitian, ditemukan bahwa telah terjadi flypaper effect belanja desa pada kampung di Kabupaten Siak. Kampung di Kabupaten Siak memiliki 
ketergantungan yang cukup besar terhadap pendapatan transfer. Oleh karena itu, diperlukan upaya bagi aparat pembuat regulasi untuk menetapkan opsi fiskal terkait kebijakan bantuan transfer bagi pemerintah desa dan kebijakan terkait pengoptimalan pendapatan asli desa. Berdasarkan keterbatasan penelitian di atas, bagi peneliti selanjutnya sebaiknya memasukkan variabel independen lainnya seperti Bagian dari Hasil Pajak dan Retribusi serta Bantuan Keuangan dari APBD Provinsi dan Kabupaten/Kota; Penelitian berikutnya diharapkan dapat memperluas wilayah penelitian tidak hanya pada desa di satu Kabupaten, sehingga hasil penelitian dapat digeneralisasi.

\section{REFERENSI}

Amalia, F. (2017). Flypaper Effect of Regional Expenditures and It's Impact to Regional Inequality in Indonesia. Jurnal Ilmu Ekonomi Volume 6 (1). P-ISSN: 20872046.

Andari, et.al. (2017). Optimalisasi Pengelolaan Pendapatan Asli Desa Untuk Meningkatkan Pembangunan Perekonomian Desa Kabupaten Buleleng.

Cristian F. S. (2012). Substitution and Income Effect of Lump-Sum Income at the Agregat Level: The Effective Budget Constraint of The Government and The Flypaper Effect. Georgia State University.

Ghozali, I. (2011). Aplikasi analisis multivariat dengan SPSS. Semarang: Badan Penerbitan Universitas Diponegoro.

Habibah, U. (2017). Analisis Pengaruh Pendapatan Asli Desa (PADesa) Dana Desa, Alokasi Dana Desa (ADD) dan Bagi Hasil Pajak dan Retribusi Terhadap Belanja Desa Bidang Pendidikan (Studi Empiris di Desa-Desa Se-Kabupaten Sukoharjo). Thesis, Universitas Muhammadiyah Surakarta.

Indrawati, S. M. (2017). Buku Saku Dana Desa. E-Book, Jakarta.

Kang, Y., \& Setyawan, D. (2012). Intergovernmental Transfer and The Flypaper Effect: Evidence from Municipalities/Regencies in Indonesia. KDI School Working Paper Series.

Kusumadewi, D. A., \& Rahman, A. (2007). Flypaper Effect Pada Dana Alokasi Umum (DAU) dan Pendapatan Asli Daerah (PAD) Terhadap Belanja Daerah Pada Kabupaten/Kota di Indonesia.

Lind, M. I., \& Wathen. (2014). Statistical Techniques in Bussiness and Economic: Chapter 12, New York: McGrow-Hill

Maimunah, M. (2006). Flypaper Effect Pada Dana Alokasi Umum (DAU) dan Pendapatan Asli Daerah (PAD) Terhadap Belanja Daerah Pada Kabupaten/Kota di Pulau Sumatera. Simposium Nasional Akuntansi Padang. 
Nurdini, R. et al. (2014). Analisis Flypaper Effect Pada Dana Alokasi Umum (DAU), Dana Alokasi Khusus (DAK), Dana Bagi Hasil (DBH), dan Pendapatan Asli Daerah (PAD) Terhadap Belanja Daerah (BD) Kabupaten/Kota di Jawa Barat. Jurnal Akuntansi dan Keuangan, Vol. 1, No. 1, ISSN: 2356-2706, Hal.79-92.

Panggabean, F. Y., \& Dalimunthe, M. B. (2017). Analysis of Flypaper Effect on District and Municipality Government Expenditures in North Sumatra Province. The $2^{\text {nd }}$

International Conference on Accounting, Business \& Economics. ISBN: 978 60261817-1-8.

Penthury, M. A. (2011). Flypaper Effects Anomaly of West Papua Capital Public Expenditure. Economic Journal Of Emerging Markets. 3(3), pp: 289-29.

Prabawa, A. (2015). Pengelolaan Alokasi Dana Desa Dalam Pembangunan di Desa Loa Lepu Kecamatan Tenggarong Seberang Kabupaten Kutai Kartanegara. E Journal Ilmu Pemerintahan. 3 (1) hal 227-238.

Peraturan Pemerintah Nomor 8 Tahun 2016 Tentang Perubahan Kedua Atas Peraturan Pemerintah Nomor 60 Tahun 2014 Tentang Dana Desa.

Peraturan Pemerintah Nomor 43 tahun 2014 Tentang Peraturan Pelaksanaan Undang Undang Nomor 6 tahun 2014 Tentang Desa.

Peraturan Pemerintah Nomor 47 Tahun 2015 perubahan PP 43 Tahun 2014 Tentang Peraturan Pelaksanaan Undang-Undang Nomor 6 Tahun 2014 Tentang Desa.

Peraturan Menteri Dalam Negeri Republik Indonesia Nomor 113 Tahun 2014 Tentang Pengelolaan Keuangan Desa.

Salawali et al. (2016). Flyppaper Effect Pada Dana Alokasi Umum dan Pendapatan Asli Daerah Serta Pengaruhnya Terhadap Belanja Daerah Kabupaten/Kota di Sulawesi Tengah. JurnalPembangunan Ekonomi dan Keuangan Daerah, Vol.18, No.2.

Saputri, M. A., \& Dul, M. (2014). Flypaper Effect Pada Dana Alokasi Umum dan Pendapatan Asli Daerah Terhadap Belanja Daerah Pada Kabupaten/ Kota Di Jawa Tengah Tahun 2011-2012. Diponegoro Jurnal of Accounting. Vol. 3, No.2. ISSN: 23373806.

Setyaningsih, I. (2017). Kontribusi Dana Desa dalam Menurunkan Angka Kemiskinan di Kabupaten Melawi. Jurnal Untan.

Sihombing, E. E., \& Anthonius, H. C. W. (2016). Flypaper Effect Pada Dana Alokasi Umum dan Pendapatan Asli Daerah Terhadap Belanja Daerah Di Provinsi Papua. Jurnal Akuntansi dan Keuangan. Vol. 11, No. 1, pp. 29-37.

Solikin, (2016). Analisis Flypaper Effect Pada Pengujian Pengaruh Dana Alokasi Umum, Pendapatan Asli Daerah, Sisa Lebih Pembiayaan Anggaran Terhadap Belanja Pemerintah Daerah Di Indonesia. Jurnal Akuntansi dan Bisnis. Vol.16, No.1, hal 1125.

Sugiyono. (2011). Metode Penelitian Kuantitatif Kualitatif dan R\&D. Bandung: Alfabeta. 
Sujarweni, V. W. (2015). SPSS Untuk Penelitian. Yogyakarta: Pustaka Baru Press.

Sulistiyoningtyas, L. (2017). Pengaruh Alokasi Dana Desa dan Pendapatan Asli Desa terhadap Belanja Desa di Kecamatan Baron. Simki Ekonomic, Vol. 01, No. 03, ISSN: BBBB BBBB.

Tuasikal, A. (2008). Pengaruh DAU, PAD, dan PDRB Terhadap Belanja Modal Pemerintah Daerah Kabupaten/Kota di Indonesia. Jurnal Telaah dan Riset Akuntansi. Vol. 1 No. 2

Turnbull, G. K. (1998). The Overspending and Flypaper Effect of Fiscal Illusion: Theory and Empirical Evidence. Journal of Urban Economics. Vol. 44, No. 1, pp. 1-26.

Undang-Undang Nomor 6 Tahun 2014 tentang Desa.

Yuni, E. P. (2017). Analisis Pengaruh Pendapatan Asli Desa (PADesa), Alokasi Dana Desa (ADD) dan Bagi Hasil Pajak dan Retribusi Terhadap Belanja Desa Bidang Kesehatan (Studi Empiris di Desa-Desa Se-Kabupaten Sukoharjo). Thesis. Universitas Muhammadiyah Surakarta.

Kartika, M. (2019). Kemendagri Sebut Dana Desa Jadi Sumber Anggaran Utama Desa. https://nasional.republika.co.id/berita/q18ozp382/kemendagri-sebut-dana-desa-jadi sumber-anggaran-utama-desa. Diakses 20 Juni 2020. 